\title{
The Food and Nutrition Surveillance System Using Indicator and Analysis of Composite
}

\author{
Fickry Faisya $^{1}$, Anita Rahmiwati ${ }^{2}$, Ari Wedhasmara ${ }^{3}$ \\ ${ }^{1}$ Public Health Faculty, Universitas Sriwijaya, Indonesia \\ ha.fickry@gmail.com \\ ${ }^{2}$ Public Health Faculty, Universitas Sriwijaya, Indonesia \\ anitafkmunsriegmail.com \\ ${ }^{3}$ Department of Information System, Faculty of Computer Science, Universitas Sriwijaya, Indonesia \\ a_wedhasmara@unsri.ac.id
}

\begin{abstract}
The problem of food's insecurity is multidimensional so that the solution's approach cannot depend on one side improvement. One of the ways to handle food's insecurity and knowing the food's security rate and vulnerability in a region is by arrangement of Food Security and Vulnerability Atlas (FSVA). Objective: This research aims to get food security and vulnerability atlas in Ogan Komering Ilir (OKI) region. Method: FSVA using indicator and analysis of composite. Result: The result was obtained from mapping based on the parameter of road's rating indicator that cannot be passed by four-wheel vehicles. It was obtained dominantly very vulnerable in 18 districts, except Tanjung Lubuk district that showed very secure and Jejawi district showed quite vulnerable. Based on the parameter of percentage's indicator in which its electricity did not available yet, 9 districts showed very vulnerable, 4 districts showed vulnerable, 3 districts showed quite vulnerable and 2 districts showed secure. Based on the parameter of the citizens who did not get clean water indicator, it was obtained that 18 districts showed very secure, 5 districts secure, 1 district showed quite secure and 1 district showed very vulnerable. Based on the parameter of the citizens in below poverty's line, the indicator found that 8 districts showed very secure, 4 districts showed secure, 1 district showed quite secure and 5 districts showed quite vulnerable. Based on the parameter of the infant mortality rate, toddler's malnutrition percentage and percentage of the citizens lived $5 \mathrm{~km}$ away from public health center, the overall showed very secure. Last, based on the parameter of all of the composite obtained, 5 districts (SP Padang, Tulung Selapan, Sungai Menang, Cengal, Air Sugihan) showed quite urgent/priority 3 , then 13 districts others showed quite not urgent/priority 4. Conclusion: Food security rate priority 3 (quite urgent) is in the five districts of OKI region.
\end{abstract}

Keywords — Food security, indicator, composite's analysis, food and nutrition surveillance

\section{INTRODUCTION}

Based on the Law of Food number 18 year 2012, food security is fulfilled condition of food for the country up to the individual, which is reflected in the availability of adequate food, both in quantity and quality, that is safe, diverse, nutritious, equitable, and affordable and does not contradict religion, beliefs, and culture, to be able to live healthy, active and productive. The availability of insufficient food will have an impact on the social, and economic security in the region and can lead to an area that is susceptible to experience food insecurity.

The problem of food insecurity is a multidimensional so that the solutions's approach cannot depend on one side improvement. One of the efforts to address food insecurity and to determine the level of resilience and food insecurity in the region is through the formulation of Resilience and Vulnerability Food or Food Security and Vulnerability Atlas (FSVA). FSVA based on the three pillars of food security is namely (1) the availability of food, (2) access to food, and (3) the use of food [1].

Since 2010, the Food Security has perfected an analysis tool monitoring food and nutrition situation known as Alert System for Food and Nutrition (FNS). Alert System for Food and Nutrition (FNS) based on the Minister of Agriculture / Chief Executive of the Food Security Council Number 43 Year 2010 on Guidelines Alert System for Food and Nutrition is a series of processes to anticipate the incidence of food insecurity and malnutrition through the collection, processing, storage, analysis, and dissemination to update food and nutrition situation. FNS results can be used as a basis for implementing an investigation to determine the extent and incidence of food insecurity and malnutrition in field of intervention in order to achieve food security community [2]. 
South Sumatra is one of the provinces in Indonesia predicated as the national food concern, but it still has been categorized as a food-insecure district including Muara Enim, OKU, OKI, MURA, MUBA, Banyuasin, OKUS, OKUT, and OI. Ogan Komering Ilir (OKI) is included in the ranking of the three districts that fall into the category of food insecurity [3]. This study aimed to obtain a map of food insecurity in OKI by using indicators and composite analysis. To get the data / information as an overview of the level of resistance and food insecurity in the region, an analysis of composite indicator is used to create a map of food security.

\section{METHODS}

Model System for Food and Nutrition awareness was obtained through the analysis of quantitative data based on the analysis of Food and Nutrition Awareness by FIA (Food Insecure Atlas) and assessment Composites. The study was conducted from April to September 2016 in Ogan Ogan Ilir (OKI). The secondary data used in this study were the data in 2015. The data were collected from official sources, namely: BPS, Bappeda, Department of Agriculture, BKKBN, Public Health Service, BKP South Sumatra, and BKP OKI.

\section{A. Analysis Alert for Food and Nutrition by FIA (Food Insecure Atlas}

FIA is a tool monitoring and analyzing food insecurity, in providing information for policy makers at the central, provincial, and district level in order to develop better planning and effective and efficient target in addressing the problems of food insecurity either transient or chronic.1. Map of Vigilance Food Indonesia (national per district) is a thematic map that shows the presence of food insecurity in a region indicated by 10 indicators and grouped into three aspects / dimensions of food security, namely: Dimensions availability of food (Food Access), and absorption of food (Food Consumtion, Health, and Nutrition). The third dimension has an enormous influence on the occurrence of chronic food insecurity (chronic food insecurity) that requires long-term treatment [2]. The dimensions and indicators can be seen in Table I.
TABLE I

DIMENSIONS AND INDICATORS OF FOOD SECURITY

\begin{tabular}{|l|l|}
\hline $\begin{array}{c}\text { Dimension } \\
\text { group of } \\
\text { indicators }\end{array}$ & \multicolumn{1}{|c|}{ Indicators } \\
\hline $\begin{array}{l}\text { food } \\
\text { availability }\end{array}$ & $\begin{array}{l}\text { Consumption of normative per capita net } \\
\text { availability of the ratio of rice, corn, } \\
\text { cassava and sweet potatoes. }\end{array}$ \\
\hline $\begin{array}{l}\text { Access o food } \\
\text { and livelihood }\end{array}$ & $\begin{array}{l}2 . \% \text { of households living below the } \\
\text { poverty line } \\
\text { 3.\% of the villages that are not drivable } \\
\text { four wheels. } \\
4 . \% \text { of households do not have access to } \\
\text { electricity. }\end{array}$ \\
\hline $\begin{array}{l}\text { Health and } \\
\text { nutrition }\end{array}$ & $\begin{array}{l}\text { 5. Life expectancy at birth. } \\
\text { s. weight of the children under the } \\
\text { standard } \\
7 . \% \text { of women are illiterate } \\
\text { 8. neonatal mortality rate } \\
\text { 9.\% of people without access to clean } \\
\text { water } \\
10 . \% \text { of the population living }>\text { km } \\
\text { from health centers }\end{array}$ \\
\hline
\end{tabular}

Of the 10 indicators based on the FIA, there are 7 indicators that will be presented in a map of Vigilance of Food and Nutrition in OKI region [4], namely:

1) Parameters of Percentage Rate Indicators (\%) village impassable four wheels (X1): Very vulnerable $(>=35)$, Vulnerable $(25-<350$, Quite Vulnerable $(20-<25)$, Quite secure $(15-<20)$, Secure $(10-<15)$, Very Secure $(0-<10)$.

2) Parameters of Votes Percentage Indicators (\%) households that do not have access to electricity(X2): Very vulnerable $(>=50)$, Vulnerable $(40-<50)$, Quite Vulnerable (30 - <40), Quite secure (20 - <30), Secure $(10-<20)$, Very Secure $(0-<10)$.

3) Parameters of Infant Mortality Assessment Indicators, (X3): Very vulnerable $(>=55)$, Vulnerable (50 - <55), Quite Vulnerable (45 - <50), Quite secure (40 - <45), Secure (31 - <40), Very Secure $(<31)$.

4) Parameters of Children under Standard Weight Rate Indicator $(X 4)$ : very vulnerable $(>=55)$, Vulnerable (50 - <55), Quite Vulnerable (45 - <50), Quite secure $(40$ - <45), Secure $(31-<40)$, Very Secure $(<31)$.

5) Parameters od Rating Indicator Percentage (\%) of the population without access to clean water $(X 5)$ : very vulnerable $(>=70)$, Vulnerable $(60-<70)$, Quite Vulnerable (50 - <60), Quite secure (40 - <50), Secure $(30-<40)$, Very Secure $(<30)$. 
6) Parameters od Rating Indicator Percentage (\%) of people living $>5 \mathrm{~km}$ from the health center (X6): very vulnerable $(>=60)$, Vulnerable $(50-<60)$, Quite Vulnerable (40 - <50), Quite secure $(30-<40)$, Secure $(20-<30)$, Very Secure $(<20)$

7) Parameters od Rating Indicator Percentage (\%) households living below poverty line $(X 7)$ : very vulnerable $(>=35)$, Vulnerable $(25$ - <35), Quite Vulnerable ( 20 - <25), Quite secure $(15-<20)$, Secure $(10-<15)$, Very Secure $(0-<10)$.

\section{B. Precautions of Food and Nutrition Analysis based Composite Rating}

To determine the value of the composite in this study, the researchers used a scoring method to get the value of relevant assessment indicators. After scoring, it will be sought in the mean scores, then it was divided by the highest value of the scores. The composite map of food security will be a conclusion regarding food security in a region.

The steps that should be run to determine the composite in each district are:

1) Convert each indicator into a predetermined score. Score $60=$ Very Vulnerable Food, Score $50=$ Vulnerable Food, score 40 = Quite Vulnerable Food, score $30=$ Quite Secure Food, score $20=$ Secure Food, score $10=$ Very Secure Food.

2) Find the mean score for each sub-district by using the following formula $\Sigma=\underline{\mathrm{X} 1+\mathrm{X} 2+\mathrm{X} 3+\mathrm{X} 4+\mathrm{X} 5+\mathrm{X} 6+\mathrm{X} 7}$

Description:

$\mathrm{X}=$ Indicators of Food Insecurity Assessment

(7 indicators).

3) Handling Priority determination

$\mathrm{K}>=0.8$ Priority 1 Very Urgent

$\mathrm{K}>=0.64$ to 0.8 Priority 2 Urgent

$\mathrm{K}>=0.48$ to 0.64 Priority 3Somewhat Urgent

$\mathrm{K}>=0.32-.48$ priority 4 Somewhat Not Urgent

$\mathrm{K}>=0.16$ to 0.32 priority 5 Not Urgent

$\mathrm{K}<=0.16$ priority 6 Strongly Urgent

\section{RESULTS AND DISCUSSION}

The results of the data obtained by 7 Indicators on the 18 Districts in Ogan Ilir regency can be seen in Table 2.
TABLE II

DATA OF 7 INDICATORS ON THE 18TH DISTRICT IN OKI REGION

\begin{tabular}{|c|c|c|c|c|c|c|c|}
\hline \multirow[t]{2}{*}{ Subregion } & \multicolumn{7}{|c|}{ Year 2015} \\
\hline & X1 & $\mathrm{X} 2$ & $\begin{array}{l}\mathbf{X} \\
\mathbf{3}\end{array}$ & $\mathrm{X4}$ & X5 & $\begin{array}{l}X \\
6\end{array}$ & $\mathbf{X 7}$ \\
\hline Kayuagung & $\begin{array}{l}63.1 \\
9\end{array}$ & 38.2 & 2 & 1.18 & 25.37 & 0 & 21.15 \\
\hline SP Padang & 100 & 46.1 & 6 & 2.4 & 28.16 & 0 & 23.48 \\
\hline Pedamaran & 100 & 41 & 0 & 0.45 & 35.6 & 0 & 22.44 \\
\hline $\begin{array}{l}\text { Pedamaran } \\
\text { Timur }\end{array}$ & $\begin{array}{l}85.7 \\
1\end{array}$ & 39.7 & 2 & 0.17 & 42.6 & 0 & 6.69 \\
\hline $\begin{array}{l}\text { Tanjung } \\
\text { Lubuk }\end{array}$ & 9.1 & 60.3 & 3 & 0.05 & 16.08 & 0 & 23.48 \\
\hline Lempuing & 100 & 13.1 & 0 & 0.68 & 28.34 & 0 & 2.82 \\
\hline $\begin{array}{l}\text { Lempuing } \\
\text { Jaya }\end{array}$ & $\begin{array}{l}64.7 \\
1\end{array}$ & 41.3 & 7 & 0.08 & 26.99 & 0 & 5.02 \\
\hline Mesuji & 100 & 12.1 & 3 & 0.04 & 18.9 & 0 & 4.27 \\
\hline $\begin{array}{l}\text { Mesuji } \\
\text { Raya }\end{array}$ & $\begin{array}{l}94.1 \\
2\end{array}$ & 40.6 & 0 & 0.02 & 0 & 0 & 3.41 \\
\hline $\begin{array}{l}\text { Mesuji } \\
\text { Makmur }\end{array}$ & 95 & 32 & 0 & 0.17 & 8.64 & 0 & 4.01 \\
\hline Jejawi & 1.05 & 73.8 & 7 & 0.71 & 24.5 & 0 & 22.7 \\
\hline Pampangan & $\begin{array}{l}45.4 \\
5\end{array}$ & 59.9 & 5 & 2.26 & 24.98 & 0 & 13.24 \\
\hline $\begin{array}{l}\text { Pangkalan } \\
\text { Lampam }\end{array}$ & 100 & 55.9 & 0 & 0 & 29.49 & $\begin{array}{l}0 . \\
2\end{array}$ & 4.11 \\
\hline $\begin{array}{l}\text { Tulung } \\
\text { Selapan }\end{array}$ & 100 & 55.8 & 2 & 0 & 31.91 & $\begin{array}{l}2 . \\
4\end{array}$ & 16.68 \\
\hline $\begin{array}{l}\text { Sungai } \\
\text { Menang }\end{array}$ & 94.5 & 71.6 & 0 & 0.21 & 83.07 & $\begin{array}{l}2 . \\
2\end{array}$ & 4.65 \\
\hline Cengal & $\begin{array}{l}57.1 \\
4\end{array}$ & 100 & 5 & 0.22 & 31.18 & $\begin{array}{l}1 . \\
4\end{array}$ & 10.43 \\
\hline Air Sugihan & 100 & 53.9 & 5 & 0.9 & 38.95 & $\begin{array}{l}0 . \\
6\end{array}$ & 11.34 \\
\hline $\begin{array}{l}\text { Teluk } \\
\text { Gelam }\end{array}$ & $\begin{array}{l}42.8 \\
6\end{array}$ & 59 & 2 & 0.74 & 32.73 & 0 & 14.97 \\
\hline
\end{tabular}


A. Food security analysis based Indicators

1. Indicator Percentage (\%) of the area that cannot be passed by four-wheel vehicles.

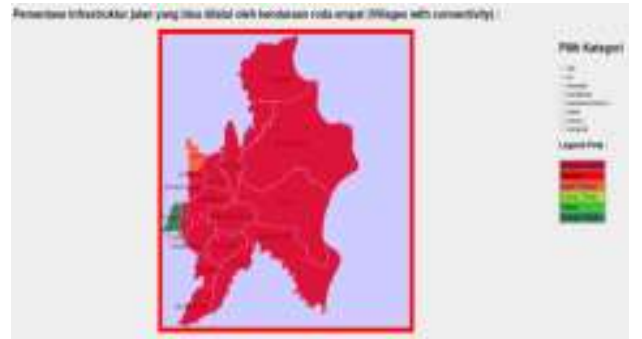

Fig.. 1 Map of the Percentage (\%) of the area that cannot be passed by four-wheel vehicles (\%)

Of the 18 sub-districts in Ogan Ilir, there are 16 sub-districts whose status is very vulnerable because they cannot be passed by four-wheeled vehicles. This is caused by the topography of the township which is an area of peat bog. Thus, it affects the road construction which becomes unstable and the road tend to be damaged easily since it is traversed by thousands of trucks from different regions. According to 5, the condition of the infrastructure will have an impact on food price in the region due to poor road conditions. This will also increase the transportation costs that will result in higher food prices.

\section{Indicator Percentage (\%) of Electricity that is} not available yet

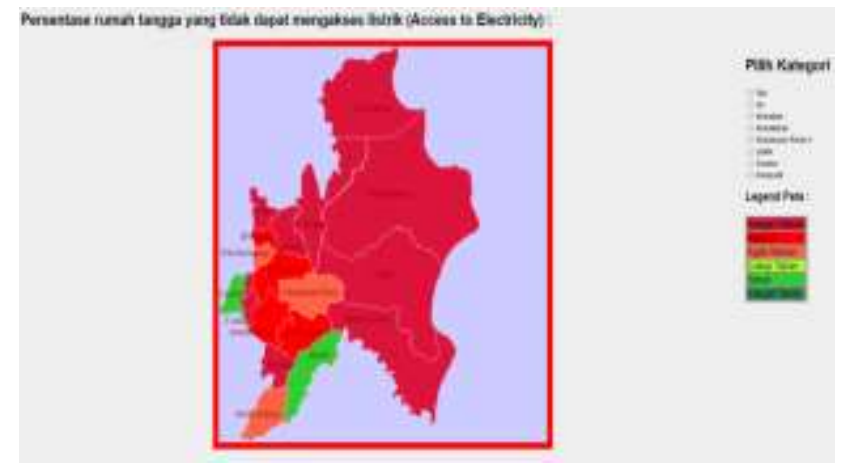

Fig. 2 Map of the percentage of Electricity that is not available yet

Districts that are very vulnerable status of the indicator of households that cannot exist in the districts electric access are Tulung Selapan, Air Sugihan, Cengal Menang.hal River and is caused by the sub-district is an area of water, plantations, and agriculture breadth large enough so that the electrical installation is hard to do because it requires a large cost and less benefited because of the number of home users of electricity are still few and far-flung distances home. According to 6 regions with high electry city access and spread throughout the territory will increase the dynamic economic activities so as to reduce poverty.

\section{Indicators Percentage of Infant Mortality Rate}

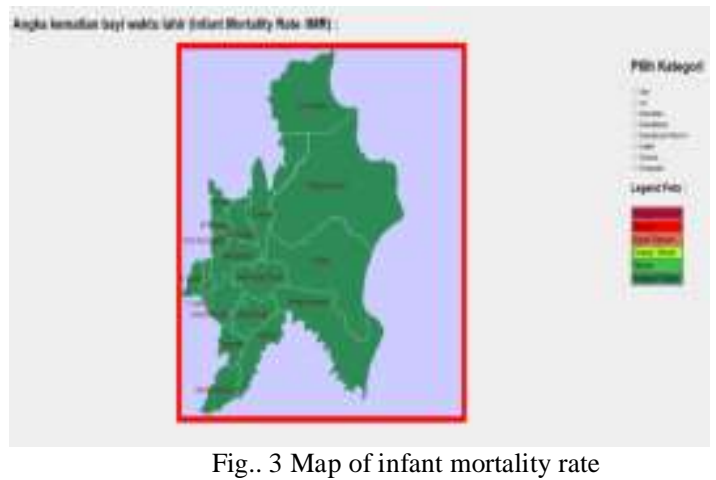

Entire districts have very resistant to the status indicator infant mortality rate because the district has an infrastructure OKI health services are evenly distributed throughout the village, good health centers, health centers, as well as poskesdes.hanya there are few villages that do not have health care. According to the impact of food insecurity is a region in child mortality [5].

\section{Indicators Percentage of toddler's malnutrition}

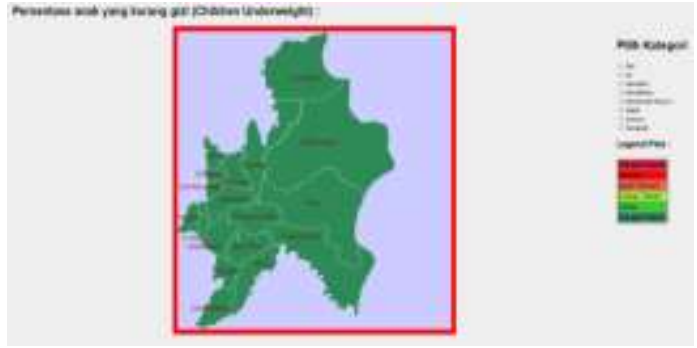

Fig. 4 Map of the percentage of toddler's malnutrition

Entire districts have status indicator is highly resistant to the percentage of toddler's malnutrition this is caused by the OIC region is an area of food production and perariran region that produce a lot of fish, so access is easier and affordable food for the people. According to5 nutritional status can be used as an indicatorof the use of food in a region. 
5. Indicator Percentage of the citizens didn't get clean water.

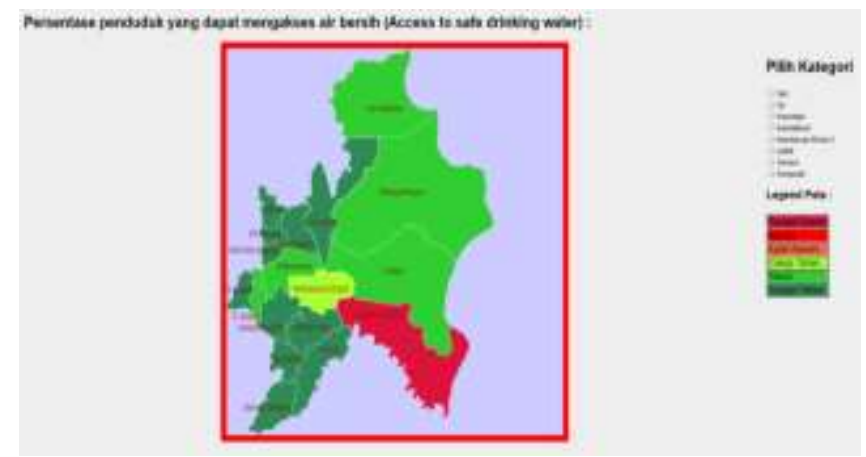

Fig. 5 Map of the percentage of the citizens didn't get clean water.

Sungai Menang is the only district that included the category of very vulnerable on the indicator percentage of the citizens have access to clean water because the area is very spacious and is a swamp area that the water contains Fe so high that access to clean water becomes difficult because it requires pipelines and budget the big one.Result study by 7 showed that indicator of sanitary dimention can use for measuring food security.

6. Indicators Percentage of the citzens lived $5 \mathrm{~km}$ away from public health centers

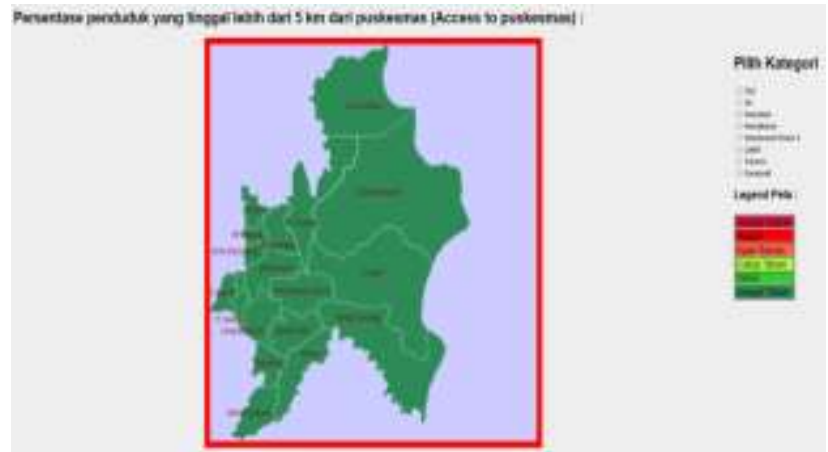

Fig. 6 Map of the percentage of the citzens lived $5 \mathrm{~km}$ away from public health centers

Entire districts have status indicator is highly resistant to the percentage of the citzens lived $5 \mathrm{~km}$ away from public health centers for OKI have the facilities and infrastructure of health services are evenly distributed throughout the village, good health centers, health centers, as well as poskesdes.hanya there are few villages that do not have health services.according to 8health facilities is very important in reducing the illness that would increase a person's ability to absorb and utilize food for the body.

7. Indicator Percentage of the citizens is in below poverty's line

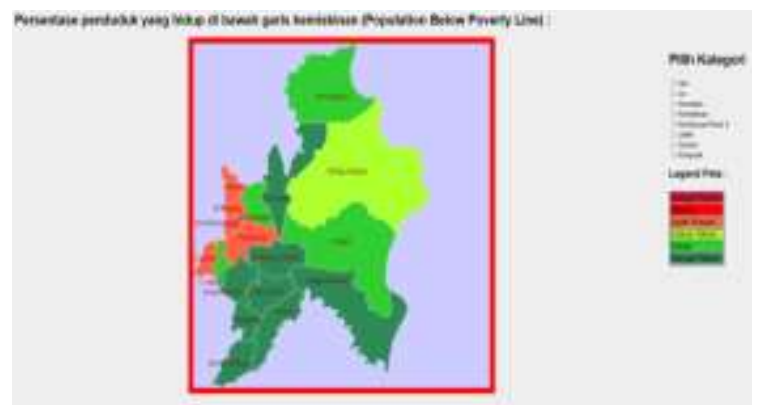

Fig. 7 Map of the percentage of the citizens is in below poverty's line

There are 5 sub-status indicator is rather prone to the percentage of people living below the poverty which is in the district Sirah Padang island, Pedamaran, Jejawi and Tanjung Lubuk. The area is rain-fed rice-fields crop failures during the last 8 years, so the impact on increasing levels of poverty every year. Besides that, in other districts can achieve the production target well.According to 6 proverty can contribute to food security. Poor lowincome residents will have difficulty in accessing food which resulted in low levels of food comsumption resulting in food insecurity.

\section{B. Food Security Analysis Based Composites value}

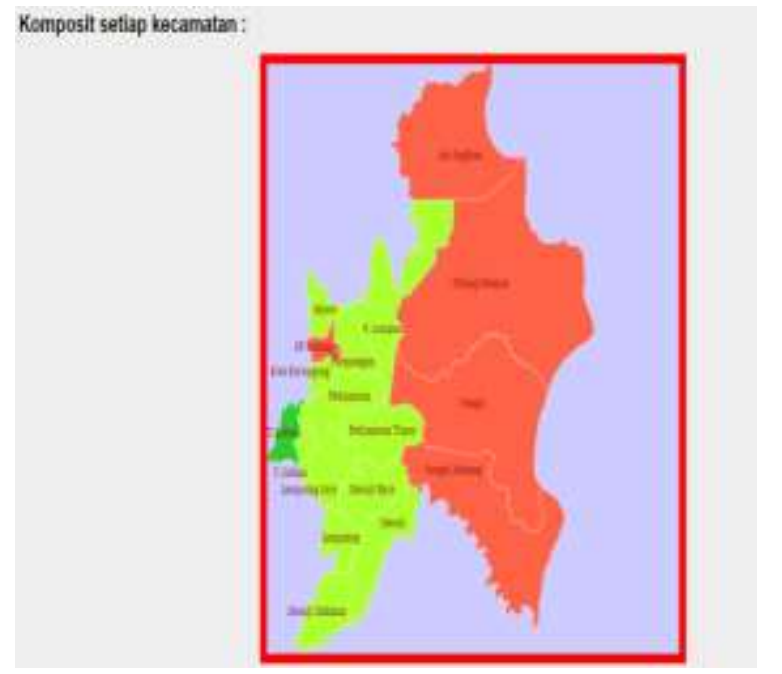

Fig. 8 Map based on a composite analysis of food security 
Based on the analysis of composite are 5 districts (SP Padang, Tulung Selapan, Win River, Cengal, Air Sugihan) the status of priority 3 , and 13 other districts entry pasa priority category 4 .

\section{CONCLUSIONS}

There are five districts in the OIC region, resilience in the category of priority 3 , namely in the district SP Padang, Tulung Selapan, Win River, Cengal, and Air Sugihan.

\section{REFERENCES}

[1] FAO, "Food Security and Vulnerability Atlas 2015 : Summary Version".

[2] K. Pertanian, "Pedoman Sistem Kewaspadaan Pangan dan Gizi Tingkat Pusat".

[3] B. K. P. P. S. Selatan, "Laporan Sistem Kewaspadaan Pangan dan Gizi Provinsi Sumatera Selatan 2015," Badan Ketahanan Pangan Provinsi Sumatera Selatan, Palembang, 2015.

[4] Suhartono, "Indikator dan Pemetaan Daerah Rawan Pangan dalam Mendeteksi Kerawanan Pangan di Kecamatan Tanjung Bumi Kabupaten Bangkalan,” Embryo, vol. 7, no. 2, pp. 97-110, Desember 2010.

[5] Y. Purwaningsih, "Ketahanan Pangan : Situasi, Permasalahan, Kebijakan, dan Pemberdayaan Masyarakat," Jurnal Ekonomi Pembangunan, vol. 9, no. 1, pp. 1-27, Juni 2008. 